\title{
MFHAS1 wt Allele
}

National Cancer Institute

\section{Source}

National Cancer Institute. MFHAS1 wt Allele. NCI Thesaurus. Code C54311.

Human MFHAS1 wild-type allele is located in the vicinity of 8p23.1 and is approximately $107 \mathrm{~kb}$ in length. This allele, which encodes MASL1 protein, may play a role in cell cycle regulation and oncogenesis. MASL1 allele is a potential oncogene whose expression is enhanced in some malignant fibrous histiocytomas. 